Reprinted with permission from: Weed Technology. 1991. 5(4):881-883.

Published and copyrighted by: Weed Science Society of America. http://www.wssa.net

\title{
Leafy spurge (Euphorbia esula) response to single and repetitive picloram treatments ${ }^{1}$
}

\author{
D. G. HEIN and S. D. MILLER
}

The authors are a former Graduate Student (now Director, Billings Institute of Religion, Billings, MT 59101) and Prof. Weed Sci., P.O. Box 3354, University of Wyoming, Laramie, WY 82071, respectively.

\begin{abstract}
:
A 4-year field study was conducted near Grassrange, MT to determine the effects of single and repetitive picloram-treatments for leafy spurge control in a native pasture. Single applications of picloram at $0.28,0.56,0.84$, and $1.12 \mathrm{~kg}$ ae ha ${ }^{-1}$ averaged $0,5,22$, and $61 \%$ leafy spurge shoot control 3 years after treatment. Only the single applications of picloram at 1.68 and $2.24 \mathrm{~kg} \mathrm{ha}^{-1}$ maintained leafy spurge control above $80 \%$. A retreatment with $0.56 \mathrm{~kg} \mathrm{ha}^{-1}$ picloram was required to maintain effective control for 3 years when less than $1.68 \mathrm{~kg} \mathrm{ha}^{-1}$ was applied. Leafy spurge canopy cover in the 1.68 and $2.24 \mathrm{~kg} \mathrm{ha}^{-1}$ treatments averaged 14 and $6 \% 3$ years after treatment; however, all other single applications required retreatment.
\end{abstract}

Nomenclature:

Picloram, 4-amino-3,5,6-trichloro 2-pyridinecarboxylic acid, leafy spurge, Euphorbia esula L., \#² EPHES.

\section{Introduction}

Effective, long-term chemical control of leafy spurge can be difficult and expensive to achieve. Application of picloram at a rate of $2.2 \mathrm{~kg} \mathrm{ha}^{-1}$ has resulted in 94 to $100 \%$ leafy spurge control $(1,6,7)$. This treatment costs over $\$ 200$ per hectare but maintained $90 \%$ control over a period of 3 to 4 years before retreatment was necessary $(1,6,8)$.

\footnotetext{
${ }^{1}$ Received for publication Jan. 28, 1991, and in revised form Aug. 13, 1991. Published with the approval of the Director, Wyoming Agric. Exp. Stn. as J. Art. No. 1644. This project was partially financed by the Wyoming Dep. of Agric.

${ }^{2}$ Letters following this \# symbol are a WSSA-approved computer code from Composite List of Weeds, Revised 1989. Available from WSSA, 309 W. Clark St., Champaign, IL 61820.
} 
Studies have shown high rates of picloram application to leafy spurge-infested pasture resulted in increased grass production; however, the cost of herbicide application necessary for effective, long-term leafy spurge control can far exceed the value of additional grass production and increased forage use by livestock on many native pasture and rangeland sites $(2,5,7)$. Total potential production and value of forage will determine if a treatment is cost-effective at a given site (8).

Although reduced rates of picloram are less expensive to apply, control of leafy spurge is limited (6). Further, since cattle avoid grazing in areas with even a $10 \%$ infestation $(3,4)$, treatments that provide only short-term shoot control are of minimal value. The purpose of this research was to determine: a) the efficacy of picloram application rates from 0.28 to $2.24 \mathrm{~kg} \mathrm{ha}^{-1}$ and b) to compare the effectiveness of single and repetitive picloram treatments for leafy spurge control.

\section{Materials and methods}

The response of leafy spurge to single and repetitive picloram treatments was evaluated in field plots during the 1985, 1986, 1987, and 1988 growing seasons. The study was located near Grassrange, MT on a dense stand of leafy spurge growing in association with cool season native grasses. The sandy clay loam soil on the test site was a fine mixed Udic Haploboroll of the Loken series with $3.5 \%$ organic matter, $7.0 \mathrm{pH}$, and an average depth of $56 \mathrm{~cm}$. Grasses present were bluebunch wheatgrass (Agropyron spicatum (Pursh.) Scribn. and Smith), slender wheatgrass (Elymus trachycaulus (Link) Gould ex Shinner), desert wheatgrass (Agropyron desertorum (Fisch.) Schult.), prairie junegrass (Koeleria cristata (L.) Pers.), needle-and-thread (Stipa comata Trin. \& Rupr.) and Kentucky bluegrass (Poa pratensis L.).

Herbicide treatments were applied with a tractor-mounted boom sprayer delivering $280 \mathrm{~L} \mathrm{ha}^{-1}$ at $275 \mathrm{kPa}$. Original (single) treatments were applied on May 16, 1985 and repetitive treatment applications were made on May 17, 1986 and again on May 14, 1987. Treatments were applied when leafy spurge was 10 to $40 \mathrm{~cm}$ tall and in the early bud to mid-flowering growth stage. The 5 by $29 \mathrm{~m}$ research plots, were arranged in a randomized complete block design with four replications. All data were subjected to analysis of variance and treatment means were separated by Fischer's Protected Least Significant Difference (LSD) test at the $5 \%$ level of significance.

Leafy spurge shoot density was determined in four $0.25-\mathrm{m}^{2}$ permanent density sampling sites located in each plot. The number of sampling sites was based on Pieper's (9) sample size estimate technique. All uninjured leafy spurge shoots were counted each May before herbicide application and percentage control based on PRE and POST-treatment shoot counts. Live leafy spurge canopy cover was determined with a ten-pin vertical point frame. A tape was stretched diagonally through each plot and ten permanent observations made. Each May before herbicide application 100 points were taken at the same site in each plot along the diagonal transect.

Page 2 of 4 


\section{Results and discussion}

All picloram treatments provided at least short-term top growth control of leafy spurge (Table 1). Leafy spurge shoot control 1 year following treatment averaged 43, 74, $83,97,98$, and $99 \%$ when picloram was applied at $0.28,0.56,0.84,1.12,1.68$, and 2.24 $\mathrm{kg} \mathrm{ha}^{-1}$, respectively. Leafy spurge control declined an average of $37 \%$ the second year and $52 \%$ the third year following single applications of picloram at $1.12 \mathrm{~kg} \mathrm{ha}^{-1}$ or less. Leafy spurge control declined an average of only $5 \%$ the second year and $6 \%$ the third year following single applications of picloram at 1.68 and $2.24 \mathrm{~kg} \mathrm{ha}^{-1}$.

All repetitive treatments except picloram at 1.68 plus $0.56 \mathrm{~kg} \mathrm{ha}^{-1}$ increased leafy spurge shoot control compared with areas receiving the single treatment (Table 1). Leafy spurge shoot control at the end of the study was 44 and 55\% higher in plots receiving one or two repetitive picloram applications than in plots receiving only the original picloram treatment of 0.28 to $1.12 \mathrm{~kg} \mathrm{ha}^{-1}$, respectively.

Table 1. Leafy spurge control and canopy cover in response to single and repetitive picloram treatments.

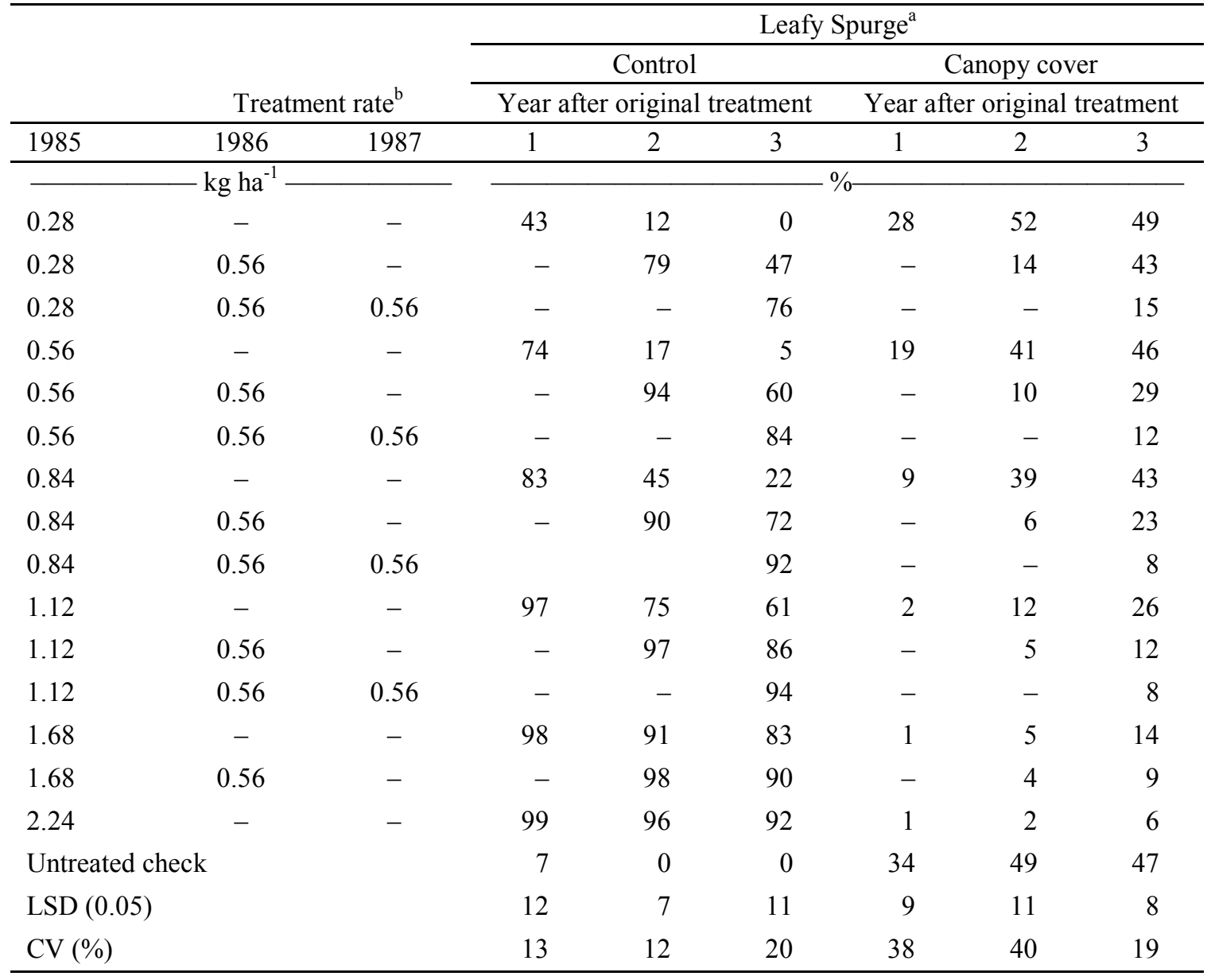

${ }^{a}$ Data collected in mid-May 1, 2, and 3 years following herbicide application.

${ }^{\mathrm{b}}$ Treatments applied May 16, 17, and 14 in 1985, 1986, and 1987, respectively. 
Compared to the untreated control, all treatments except picloram at $0.28 \mathrm{~kg} \mathrm{ha}^{-1} \mathrm{sig}^{-}$ nificantly reduced leafy spurge canopy cover 1 year after treatment (Table 1). Canopy cover actually increased slightly over pretreatment levels with this treatment (data not shown). Leafy spurge canopy cover increased in all single picloram applications 2 years following treatment compared to levels after the first year except at 1.68 and $2.24 \mathrm{~kg} \mathrm{ha}^{-1}$. For example, picloram applied at 0.56 and $0.84 \mathrm{~kg} \mathrm{ha}^{-1}$ reduced leafy spurge canopy cover 44 and $74 \%$, respectively, 1 year following treatment but by the second year canopy cover in these treatments was similar to the untreated check. The minimum picloram rate required to maintain a reduction in leafy spurge canopy cover for 3 years compared to the untreated control was $1.12 \mathrm{~kg} \mathrm{ha}^{-1}$.

All repetitive treatments, except with picloram at 1.68 plus $0.56 \mathrm{~kg} \mathrm{ha}^{-1}$, decreased leafy spurge canopy cover compared with areas receiving the single treatment (Table 1). Leafy spurge canopy cover at the end of this study was 14 and 30\% lower in plots receiving one or two repetitive picloram treatments, respectively, than in plots receiving only the original picloram treatments of 0.28 to $1.12 \mathrm{~kg} \mathrm{ha}^{-1}$.

This research indicates that picloram retreatments were required to maintain effective leafy spurge control and canopy cover reductions for 3 years when the original application rate was less than $1.68 \mathrm{~kg} \mathrm{ha}^{-1}$. Leafy spurge control and canopy cover 3 years following application of the original treatments was similar in all plots receiving $1.68-\mathrm{kg} \mathrm{ha}^{-1}$ picloram whether applied as a single or repetitive treatment. A number of factors including accessibility, application costs, carrying capacity, forage production,

and forage value will determine the most cost-effective approach to applying $1.68 \mathrm{~kg} \mathrm{ha}^{-1}$ picloram at a given site.

\section{Literature cited}

1. Alley, H. P., R. E. Vote, and T. D. Whitson. 1982. A summary of original and three repetitive herbicide treatments for control of leafy spurge (Euphorbia esula L.). In: Leafy Spurge Control in the Great Plains. GPC 14:69-74.

2. Gylling, S. R., and W. E. Arnold. 1985. Efficacy and economics of leafy spurge (Euphorbia esula L.) control in pasture. Weed Sci. 33:381-385.

3. Hein, D. G. 1988. Single and repetitive picloram treatments on leafy spurge (Euphorbia esula L.) and resulting changes in shoot density, canopy cover, forage production and utilization by cattle. Ph.D. thesis. Univ. of Wyo. Univ. Microfilms. Ann Arbor, MI (Diss. Abstr. AAD 88-27917).

4. Lym, R. G., and D. R. Kirby. 1987. Cattle foraging behavior in leafy spurge (Euphorbia esula)-infested rangeland. Weed Technol. 1:314-318.

5. Lym, R. G., and C. G. Messersmith. 1983. Control of leafy spurge with herbicides. N.D. Farm Res. 40(5):16-19.

6. Lym, R. G., and C. G. Messersmith. 1985. A summary of leafy spurge control with herbicides in North Dakota. 20-year summary. J. Range Manage. 38:149-154.

7. Lym, R. G., and C. G. Messersmith. 1985. Leafy spurge control and improved forage production with herbicides. J. Range Manage. 38:386-391.

8. Lym, R. G., and C. G. Messersmith. 1990. Cost-effective long-term leafy spurge (Euphorbia esula) control with herbicides. Weed Technol. 4:635-641.

9. Pieper, R. D. 1973. Measurement Techniques for Herbaceous and Shrubby Vegetation. New Mexico State Univ., Las Cruces, NM. 148 p.

Page 4 of 4 